\title{
Peertechz
}

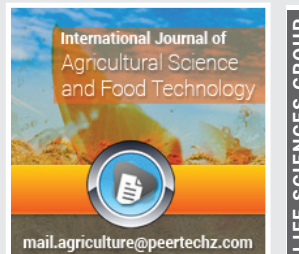

\section{Review of highland sorghum improvement research in Ethiopia}

\section{Zigale Semahegn* and Temesgen Teressa}

Ethiopian Institute of Agricultural Research, Melkassa Agricultiral Research Center, National Sorghum research program, Ethiopia
Received: 27 October, 2021

Accepted: 09 November, 2021

Published: 10 November, 2021

${ }^{*}$ Corresponding authors: Zigale Semahegn, Ethiopian Institute of Agricultural Research, Melkassa Agricultura Research Center, P.O Box 436, Adama, Ethiopia, Tel: +251911580509; Email: zigalesemahegn@gmail.com

Keywords: Highland; Sorghum; Improvement

Copyright: (c) 2021 Semahegn Z, et al. This is an open-access article distributed under the terms of the Creative Commons Attribution License, which permits unrestricted use, distribution, and reproduction in any medium, provided the original author and source are credited.

https://www.peertechzpublications.com

\section{Abstract}

Sorghum is the most well-known helpful cereal crop for poor farmers in Ethiopia's dry lowland areas due to it's a high yielding, drought tolerant, nutrient use efficiency crop that can be grown over $80 \%$ of the worlds' cultivated land. It has many advantages in the economic lives of the farmers in the highlands of the country. It is a source of food, feed, fuel, construction, fencing to poor farmers of Ethiopia. Though, many biological and environmental stresses are reducing grain yield increment. Foliar and grain diseases are one of the main biological stresses limiting sorghum production and productivity in the high and intermediate rainfall areas of Ethiopia. Therefore, the objective of this paper is to review the current state of highland sorghum improvement in Ethiopia's highlands. Breeders, pathologists, agronomists, and research extension workers have all worked hard to overcome the constraints. In addition, the national sorghum research program is focusing on developing tolerant varieties that can withstand a variety of pressures by backcrossing tolerant characteristics into existing potential landraces and elite advanced lines. Due to many yieldlimiting conditions, the crop's production is well below its potential. Sorghum breeding began in Ethiopia in the early 1950 s to solve important production difficulties that contributed to low productivity, and as a result, a number of improved varieties have been offered to farmers. Since 1978, research and development efforts previous to Ethiopian sorghum enhancement have been studied. Generally, believe that future productivity will most likely increase as a result of the integration of a diverse collection of mutually beneficial disciplines and organizations with varying priorities in technology development, advancement, promotion, and market/product production. Multidisciplinary methodologies, system sustainability with temporal and spatial intensification, and participation of essential stakeholders, including farmers, in the technological development, increase, promotion, and proper intervention in production are also of interest.

\section{Introduction}

Sorghum [Sorghum bicolor (L.) Moench] is a droughttolerant, nutrient-efficient crop that can be cultivated in over $80 \%$ of the world's ecologies. It is primarily grown in Ethiopia's intermediate, wet lowland, highland, and dry lowland agroecological zones [1]. High altitude (> 1900 masl), high rain falls (1000mm), and low temperature characterize Ethiopia's highland agro-ecologies. Highland sorghum production accounts for only $10 \%$ of total sorghum production [2], and it is declining in some parts of Ethiopia's highlands, such as the Western and Eastern Hararghe areas, as farmers shift from sorghum to maize production, which pays well when the maize reaches dough stage in a short time (Personal Information). Sorghum is the fifth most significant cereal crop in the world, and it ranks third in Ethiopia in terms of area coverage and production [3]. It is used in a variety of ways, including traditional meals such as Injera, local bread, porridge, and beverages such as Tella and Bordede. Furthermore, sorghum biomass is essential for animal feed, building, biofuel, and fencing for Ethiopia's poor farmers. To satisfy these needs, the country possesses a variety of sorghum germplasm resources that help sorghum-growing communities and are used in interventions to generate better sorghum varieties that boost sorghum production and nutritional quality [4].

Despite its huge economic benefits, sorghum production and productivity are limited by a variety of biological and environmental reasons. Grain mold and Anthracnose diseases are two biological issues that cause limit sorghum output in Ethiopia's intermediate and highlands. Aside from that, there are limitations to improved varieties, such as other striga and disease-tolerant improved varieties, low farmer adoption of better varieties, poor farmer participation during selection, 
frost, and poor soil fertility, such as soil acidity and nutrition. Breeders, pathologists, agronomists, and research extension workers have all contributed to overcoming the constraints. Therefore, developing of tolerant/resistant varieties that withstand a wide array of stress through introgression of tolerant/resistant traits into existing potential landraces and elite advanced lines.

In addition, the agro-processing use of sorghum is mostly attributable to the production of infant meals and feed products. The physical characteristics and nutritional properties of sorghum products, as well as knowledge and awareness gaps and consumer perceptions, continue to be important impediments to sorghum's competitiveness. The system's complexity necessitates collaboration between empirical research, agribusinesses, and development players in order to improve nutrition, capacity development, product innovation, and demand creation. Furthermore, increasing farm productivity, encouraging farmer-industry relationships, and providing backups to the fledgling agro-processing sector are also possibilities.

The quantity of genetic variability among the genetic material under consideration, the heritability of a specific characteristic in a given environment, and the level of selection intensity employed all influence breeding progress (Falconer, 1989). It is critical to expand the genetic base of source materials by developing source materials of these highland sorghums for prospective settings, biotic and abiotic challenged conditions, and unique end-use attributes. Aggressive hybridization, landrace collecting, and introductions efforts could help achieve this.

Various findings on the improvement of sorghum in the country's high altitude agro-ecologies have been studied [5-7]. For the past five decades, the National Agricultural Research, in collaboration with other local and international research organizations, has contributed to the country's agricultural development. The prior research potential produced for the past fifty years to modify the situation of low sorghum crop productivity in highland areas has resulted in the creation of several enhanced production technologies appropriate for subsistence farmers. Extension systems at the regional and federal levels have shown the highest levels of research developed technologies as related to farmers' own experiences in recent decades, indicating that EIAR has been a leading institution in emerging and popularizing agricultural technologies throughout Ethiopia. As a result, farmers have access to a wide range of enhanced varieties. Similar attempts persisted after that, but despite the critical value of such data for crop improvement, the results were not systematically summarized and published. As a result, the purpose of this review is to review the status of highland sorghum improvement research in Ethiopia.

\section{Constraints of highland sorghum production}

The country is located in a region of the world where human suffering and poverty due to food scarcity are most prevalent. The major limits to highland sorghum production in Ethiopia that result in decreased production and productivity are connected to factors resulting from adverse environmental (abiotic stresses) and biological (biotic stresses) conditions for crop production and growth. The major biological factors are grain and leaf diseases, as well as parasitic weeds, which have resulted in significant sorghum grain yield losses in terms of both quality and quantity while the abiotic factors include soil nutrient depletion, soil acidity, frost, and low external inputs with poor agronomic practices used by the farmers.

Farmers can try to improve their farming situation, but it is well known that the farmer's own creative capacity can only provide a minor improvement over recent experience, and that further fundamental change can only be achieved if farmers are assisted with formal science-based knowledge [8]. Although many improved technologies for various sorghum varieties have been released and developed as a result of research efforts made thus far, the release of technologies did not mean much in and of itself because they were not well promoted, popularized, multiplied and made available to farmers, and eventually adopted. Most of the country's growing areas are still using the conventional production system, despite the fact that developed sorghum technologies have not yet to be fully implemented.

\section{Opportunities of highland sorghum production}

Ethiopia is recognized as the centers of genetic diversity or origin for various essential crops [9]. The country owns large and diverse indigenous sorghum germplasm resources, which are genetically different and this genetic potential is not yet adequately exploited. The diverse and suitable production systems and production environment provides opportunities for development of alternative feed and food resource base. Diverse sorghum genetic resources are maintained by Institute of Biodiversity and national sorghum research program. These resources are pre-requirements for sorghum crop improvement. The highest majority of farmers rely on these species of sorghum next to teff and maize in agricultural production activities. The opportunities for highland sorghum production in Ethiopia are high annual rainfall distributions, low temperatures, and favorable government policies that assist agriculture.

Ethiopia is known as a center of genetic diversity or origin for a variety of important crops [9]. The country has extensive and diversified indigenous sorghum germplasm resources, all of which are genetically distinct, and this genetic potential has not yet to be fully realized. The development of alternative feed and food resource bases is possible due to the diversified and adequate production methods and production environment. The Institute of Biodiversity and the national sorghum research program both conserve diverse sorghum genetic resources. These resources are prerequisites for improving sorghum crops. Sorghum species, together with teff and maize, are used by the vast majority of farmers in agricultural output.

\section{Historical background of highland sorghum research in Ethiopia}

Sorghum research in Ethiopia began in the mid-1950s at Alemaya University, and it has played an important role in the 
development of sorghum cultivars for highland environments with the help of American people (USAID), while local collections and introductions were screened for high yield and adaptability to highland environments. In the late 1960s, the Ministry of Agriculture established the National Crop Improvement Committee, and the Alemaya University was given national responsibility for sorghum improvement. This national role included managing all experimental stations' yearly sorghum National Yield Trials (NYT) (Sorghum Improvement Program, 1978). Melkassa Agricultural Research Center currently coordinates the national sorghum research program, while Chiro National Sorghum Research and Training Center coordinates highland sorghum research with the help of a variety of federal and regional research institutes. The major goal of highland sorghum research is to develop and promote improved sorghum technologies that improve production, usage, and food security in Ethiopia's Highland agro-ecologies. Multivariate approaches based on the biotic responses of sorghum cultivars were used to arrange the test environments into groups with similar ranking of all genotypes and a similar size of $\mathrm{G} \times \mathrm{E}$ interaction, which has substantial implications for the biotic responses of the sorghum cultivars. At the collaborating centers, team spirit is in full swing in order to maintain the same multidisciplinary methodologies.

\section{Sorghum genetic variability and potential in Ethiopia}

Any crop breeding and/or improvement program must have access to a diverse set of germplasm resources. Furthermore, the simplicity with which germplasm resources can be accessed and characterized is critical for successful and efficient use in crop research projects. Any agricultural research program's success is dependent on a variety of germplasm resources and the selection of superior parents with a variety of desirable traits (Dinesh et al., 2010). Crop diversity research aids in the understanding of intra-species crop performance, which can be used to improve crops [10], as well as providing evidence of genetic divergence. It also serves as a foundation for specific breeding goals [11] and identifies parental pairings that can be used to produce heterogeneous populations with a high genetic potential for more selection (Dagnachewet al., 2017).

Despite the fact that Ethiopia is a center and source for a variety of crop species such as coffee, sorghum, Tef, chickpea, and others, the country is densely populated with wild kinds and landraces that have adapted to a variety of agro-ecological conditions [12]. The country has a huge amount of sorghum variability since it is a center of sorghum genetic variation [13]. Except for kafir, Ethiopia cultivates all five basic races of sorghum morphology (guinea, bicolor, caudatum, durra, and kafir) [14]. The Country sorghum accessions have been connected to grain yield [15,16], insect resistance [17], cold tolerance [18], and protein quality $[15,16,19,20]$. They also perform a variety of functions related to resource maintenance, development, and use of resources [21].

Nearly 9, 824 sorghum accessions were maintained and collected by the Ethiopian Sorghum Improvement Program (ESIP) and the Institute of Biodiversity Conservation (IBC). The Ethiopian Institute of Biodiversity and Conservation
(EIBC) recently saved and gathered approximately 10,000 sorghum accessions from various sources. Containing various kinds of cultivated and wild cousins, they represent potential germaplasm for crop development and a source of noble qualities [22].

\section{Achievements of past highland sorghum research}

Development of sorghum Genetic Information: Genetic information is crucial for plant breeding development, and it is this knowledge that underpins the comprehensive introduction to plant breeding concepts and principles. Germplasm selection, trait inheritance in a given environment, optimal environment selection and selection criteria, germplasm characterization and testing, genotype by environment interaction information, and genotype performance stability across environments are some of the topics covered (Falconer, 1989). At the molecular and morphological levels, sorghum breeders have generated fundamental information on the degree and type of genetic diversity among highland sorghum germplasm accessions $[4,23]$. The data suggested that advancement on genetic information would be expected as a result of selection in introductions, landrace collections, and their crosses $[4,23]$. Multivariate methods based on the biotic responses of sorghum cultivars were used to divide the test environments into groups with similar ranking of all genotypes and a similar magnitude of $\mathrm{G} \times \mathrm{E}$ interaction, which has important implications for genotype evaluation and screening $[6,7,24,25]$.

Variety Development: There is no doubt that developed seed is an important background source input for getting other component technologies to farmers. Germplasm conservation and collections from the national sorghum research program, the Ethiopian Institute of Biodiversity, and the acquisition and introduction of genetic materials from international sources such as ICRISAT are all sources of variation for genetic enhancement of sorghum in Ethiopia.

The Ethiopian Institute of Biodiversity and the national sorghum research program provided many of the landrace collections used in the breeding operations. We have traditionally used the elite by elite or best by best landrace parent crossing pedigree breeding approach to combine desired qualities such as grain yield, disease tolerance/resistance, and quality from multiple parents into a single genotype.

Following the formation of genetic variation, crops with the chosen combinations of attributes in their progeny are isolated and selected. The selected populations are examined in the selection nursery for early maturity, high grain yield, disease tolerance/resistance, and seed size and color. Other biological and environmental factors relying on the condition are commonly grown in disease prone areas for collections, introductions, and segregants from crossing. During the selection process, pedigree techniques are frequently applied. The yield and other attributes of the recently selected populations are analyzed, as well as the standard check for comparison. Multi-environment studies of varieties representing Ethiopia's highland agro-ecologies have identified the most important varieties for release in terms of 
stability and performance across environments. It is obvious that if a variety developed by breeders to increase agronomic behavior is not preferred by farmers for other reasons and is not accepted at the end of the day, all of the resources invested in its improvement would be wasted. As a result, it's critical that farmers participate in testing and selection methods based on their trait preferences. To this aim, farmers are frequently included in variety testing schemes at a certain level as part of the regular technique, where it was discovered that farmers and researchers have their own distinct and common selection criteria [5]. Farmers' participation in the variety testing process is therefore critical, as selection characteristics ignored by researchers may be addressed if farmers are involved from the start. Farmers are the final users; therefore, this is expected to hasten the distribution of the released kinds. When genotypes are chosen for varieties to be finally confirmed and released, the focus is on genotypes that outperform and outlast the most recently issued variety as a check.

The national sorghum research program and Haramaya University, Ethiopia, have released and produced 16 highland sorghum varieties to producers through various interinstitutional efforts over the last fifty years [26]. If the varieties are fully approved and put into production with adequate crop management and protection packages, the yield potential and relative benefits of these varieties over existing ones revealed the potential of improving the poor national average grain yield. Previous attempts, on the other hand, were nearly entirely focused on ideal settings, with little consideration paid to all places, including highland environments (Table 1).

\section{Technology scaling-up}

As a result, a technology scaling-up program has played a key part in Ethiopia's efforts to enhance poor farmers' living

Table 1: List of released highland sorghum varieties in Ethiopia.

\begin{tabular}{|c|c|c|c|}
\hline No. & Variety & Year of release & Maintainer \\
\hline 1 & AL-70 & 1970 & MARC/EIAR \\
\hline 2 & ETS 2752 & 1978 & MARC/EIAR \\
\hline 3 & ETS 4946 & 1978 & MARC/EIAR \\
\hline 4 & ETS 717 & 1978 & MARC/EIAR \\
\hline 5 & ETS 2113 & 1978 & MARC/EIAR \\
\hline 6 & ETS 3235 & 1978 & MARC/EIAR \\
\hline 7 & ETS 2111 & 1978 & MARC/EIAR \\
\hline 8 & ETS 601 & 1978 & MARC/EIAR \\
\hline 9 & Chiro & 1998 & MARC/EIAR \\
\hline 10 & Muyra-1 & 2000 & $\mathrm{HU}$ \\
\hline 11 & Muyra-2 & 2000 & $\mathrm{HU}$ \\
\hline 12 & Chelenko & 2005 & MARC/EIAR \\
\hline 13 & Dibaba & 2015 & MARC/EIAR \\
\hline 14 & Fendisha-1 & 2015 & $\mathrm{HU}$ \\
\hline 15 & Adelle & 2016 & MARC/EIAR \\
\hline 16 & Jiru & 2016 & MARC/EIAR \\
\hline
\end{tabular}

Source: EIAR, 2019.

Where MARC = Melkassa Agricultural Research Center, EIAR = Ethiopian Institute of Agricultural Research. conditions. Almost all of the technologies that are recommended and licensed for widespread use by farmers want to be tested and demonstrated to them. These methods have been built up on huge cultivated areas of agricultural land in recent decades.

Food security, which is basically the ultimate goal of almost all breeding projects, is primarily dependent on long-term production support with suitable technical interventions. At different eras, several platforms were employed to improve research-extension-farmer linking programs. Pre-extension demonstration and technology promotion program, farmers' research groups for technology promotion, farmers field, and pre-scaling up of agriculture technologies by research centers in collaboration with other agriculture and rural development partners at the federal, regional, zonal, and wereda levels are just a few examples. All of these initiatives, as well as a few others, were designed to develop an effective interface between the research system and extension [26-30].

\section{Research and development gaps in sorghum improve- ment to value chain}

Ethiopian Institute of Agricultural Research has developed 15 years strategic plan for sorghum improvement to the customers (end users) value chain [22]. The strategic document contained both research and developmental gaps for the last five decades being challenging in the improvement of sorghum. The major research and development gaps include.

\section{Research gaps}

- Lack of improved sorghum varieties that combined grain yield, resistance/tolerance and quality that adapted to different agro-ecologies

- Inadequate popularization and dissemination of the existing technologies

- Inadequate value chain development

- Lack of value-added sorghum products

- Limited research on quality for injera making, agoprocessing (alternative market products and breweries)

- Limited research on sorghum crop management

- Information and Knowledge gap on input - output market of sorghum

\section{Developmental gaps}

- Lack of strong seed system specifically the formal seed sysytem

- Lack of supportive policy for sorghum seed system and grain marketing

- Absence of grain markets when farmers or investors produce large grain sorghum

- Most of the sorghum grain produced is sold in local markets

- Absence of agro-processing industries

Citation: Semahegn Z, Teressa T (2021) Review of highland sorghum improvement research in Ethiopia. J Agric Sc Food Technol 7(3): 335-340. 


\section{Summary and conclusion}

Sorghum improvement research initiatives have aimed to develop and benefit new production technology throughout the previous five decades, ultimately contributing to food security and increased household income in farming communities. These included the development and demonstration of new technology, as well as the distribution of early seed to farmers. The different teams were able to produce and distribute a list of sorghum varieties, as well as the best-bets of crop management and protection choices, which have been vital for the growth of the sorghum sector in this country, using a huge number of sorghum germplasm. Efforts at the regional and national levels to promote this technology to a wider user resulted in a dramatic transformation in the lives of Ethiopia's small farmers.

The main production constraints of highland sorghum in Ethiopia, which result in lower productivity and production, are related to factors such as unfavorable conditions for crop growth and production imposed by biotic and abiotic stresses, which resulted in significant sorghum yield loss in terms of quantity and quality. There were not only constraints, but also opportunities, such as the availability of starter technologies from previous research efforts, the successes of prior scalingup activities that paved the way for future similar endeavors, high annual rainfall distributions, low temperatures, and favorable government policies that support agriculture.

The need for improved production technology is projected to rise over time as more farmers become aware of the advantages. Seeds of improved varieties, especially those that meet food security requirements, have not yet been properly developed and made available to needy farmers. In terms of technological generation, in addition to local needs arising from physical conditions, farming techniques and consumer demand were not effectively handled.

Building the capacities and capabilities of the coordinating and cooperating research centers through various forms of technical, material, and financial support holds a lot of promise for generating need-based technology options, making them available to farmers, and ensuring proper promotion and application in production on a long-term basis. Through increased participation of collaborative research centers and decentralization of the research process and seed system, efforts should be made to ensure that the research and development process will continue independently to offer advantages to a large number of people quickly. Increasing the genetic diversity of source material to enable the creation of new possibilities.

It goes without saying that EIAR has been instrumental in reducing poverty and enhancing livelihoods on a national scale. The pioneering role that this prestigious Institute played early in the history of highland sorghum research resulted in the identification of cultivars as well as crop management and protection measures that raised yield, stress resistance, and quality. However, it is considered that there is still a lot of "hidden" potential in highland sorghum that may be tapped to help farmers improve their living. This potential, which can be partially released by "cracking" this hide using sophisticated scientific instruments, had only been partially realized during the previous five decades.

We must face the harsh reality that a few agricultural activities alone will not allow us to achieve maximum yields above a certain point. We often believe that combining a mutually available range of fields and organizations with varying responsibilities in technology multiplication, generation, promotion, and market/product production will boost future productivity. Multidisciplinary techniques, system sustainability with temporal and spatial intensification, and the participation of important stakeholders, including farmers, in technology multiplication, generation, promotion, and effective application in production are all areas of interest. Finally, a comprehensive approach is required, in which each field and other partners, such as donors, complement and reinforce one another.

\section{References}

1. Gorfu D, Ahmed E (2011) Crops and Agro Ecological Zones in Ethiopia. RN TIGRAY 2, April 2009. Link: https://bit.ly/31E7bY9

2. EIAR (2019) Sorghum Breeding Manual, Website. Link: http://www.eiar.gov.et

3. FAOSTAT (2018) UN Food and Agriculture Organization Statistics. 7.

4. Amsalu A, Bryngelsson T, Bekele E (2000) Genetic Variation of Ethiopian and Eritrean Sorghum (Sorghum bicolor (L.) Moench) Germplasm Assessed by Random Amplified. Link: https://bit.ly/3EZLbFK

5. Firew Y, Mekbib F, Adugna A (2016) Performance Evaluation and Participatory Varietal Selection of Highland Sorghum (Sorghum bicolor (L.) Moench) Genotypes in Western Part of Ethiopia. American-Eurasian J Agric \& Environ Sci 16: 1641-1647. Link: https://bit.ly/3bQFJIG

6. Amare S, Zigale S, Adane G (2019) AMMI and GGE bipolt analysis of Genotype $x$ Environment Interaction and Yield Stability of Pearl Millet Genotypes [Pennisetum glaucum (L.) R. Br.] in Moisture Stressed Areas of Ethiopia. Acad Res J Agri Sci Res 7. 12. Link: https://bit.ly/3oaRWh9

7. Teressa T, Bejiga T, Semahegn Z, Seyoum A, Kinfe H, et al. (2021) Evaluation of advanced sorghum (Sorghum bicolor L. Moench) hybrid genotypes for grain yield in moisture stressed areas of Ethiopia. J Agric Sc Food Technol 7: 212219. Link: https://bit.ly/3bQRRJL

8. Bunder J, Loeber A, JEW Broers. B Havertkort (1996) An integrated approach to biotechnology development. PP 201-227 In J. Bunders, B. Haverkort and W. Hiemstra (eds). Biotechnology; building on farmers' knowledge. Macmillan, London and Basingstoke.

9. Huff nagel HF (1961) Agriculture in Ethiopia. FAO, Rome.

10. Aremu CO (2011) Genetic Diversity: A review for need and measurements for intra-species crop improvement. Journal of Microbiology and Biotechnology Research 1: 80-85. Link: https://bit.ly/3wBMacc

11. Thompson JA, Nelson RL, Vodkin LO (1998) Identification of diverse soybean germplasm using RAPD markers.Crop Science. 38: 1348-1355. Link: https://bit.ly/3wBMkQQ

12. Abe Sh (2010) Biodiversity in Plant, Grain and Nutritional Characteristics of Sorghum [Sorghum bicolor (L.) Moench] Accessions From Ethiopia and South Africa; Thesis work Department of Plant Breeding ,University of the Free State Bloemfontein, South Africa. 1-20. Link: https://bit.ly/3kjkdRr

13. Adugna A (2007) The role of introduced sorghum and millets in Ethiopian 
agriculture Melkassa Agricultural Research Center, Nazareth, Ethiopia. SAT Journal ejournal.icrisat.org. 3. Link: https://bit.ly/30cD3Ts

14. Harlan JR (1972) Genetic resources in sorghum. Pp.1-13 in Sorghum in the seventies: proceedings of the International Symposium on Sorghum, 27-30 Oct (Ganga Prasad Rao N and House LR, eds.). New Delhi,India: Oxford and IBM.

15. Doggett H (1988) Sorghum, 2nd ed. UK: Longmans Scientifi c and Technical Publishers.

16. Kebede $Y$ (1991) The role of Ethiopian sorghum germplasm resources in national breeding programme. In: J.M.M. Engels,J.G. Hawkes \& M. Worede (Eds.), Plant Genetic Resources of Ethiopia. Cambridge University Press Cambridge. 315-322. Link: https://bit.ly/3c0BgD3

17. Faris MA, Lira MDE, Veiga AF, De SL (1979) Stability of sorghum midge resistance. Crop Sci. 19: 577-588. Link: https://bit.ly/3BSWmhv

18. Singh SP (1985) Sources of cold tolerance in grain sorghum. Can J Plant Sci 65: 251-257. Link: https://bit.ly/3ot06zV

19. Gebrekidan B, Kebede $Y$ (1979) The traditional culture and yield potentials of the Ethiopian high lysine sorghums. Eth J Agric Sci 1: 29-40. Link: https://bit.ly/3D2GrhK

20. Singh R, Axtell JD (1973) High lysine mutant gene (hl) that improves protein quality and biological value of grain sorghum. Crop sci. 13: 535-539. Link: https://bit.ly/3F1PwYG

21. Worede M, Tesemma T, Feyissa R (2000) Keeping diversity alive: An Ethiopian perspective. In: Brush, S.B. (Ed.), Genes in the field: On-farm conservation of crop diversity, Lewis Publishers, Boca Raton 143-161.

22. Ethiopian Institute of Agricultural Research (2014) Ethiopian strategy for sorghum 2014-2024. 1-10. Link: https://bit.ly/3BZmNIm
23. Alemu Tirfessa Tesfaye Tesso Asfaw Adugna Hussein Mohammed Hussein Mohammed (2020) Genetic diversity among Ethiopian sorghum [Sorghum bicolor (L.) Moench] gene bank accessions as revealed by SSR markers. African Journal of Biotechnology. 19: 84-91. Link: https://bit.ly/3bVs08k

24. Yan W, Tinker NA (2006) Biplot analysis of multi-environment tria data: Principles and applications. Can J Plant Sci 86: 623-645. Link: https://bit.ly/3ofhGsw

25. Seyoum A, Semahegn Z, Nega A, Siraw S, Gebereyhones A, et al. (2020) Multi-Environment Evaluation and Genotype $\times$ Environment Interaction Analysis of Sorghum [Sorghum bicolor (L.) Moench] Genotypes in Highland Areas of Ethiopia. American Journal of Plant Sciences 11: 1899-1917. Link: https://bit.ly/3qlKvqa

26. MoANR (2019) Crop variety register. Issue No. 18. Plant variety release protection and seed quality control directorate. Addis Ababa, Ethiopia.

27. Assefa K, Fikre A, Alemu D, T/Wold A (2011) Mitigating crop technologies and seed gaps: addressing the unaddressed. Ethiopian Institute of Agricultural Research, Addis Ababa, Ethiopia.

28. Poehlmann J, Sleper D (1995) Breeding Field Crops. Iowa State University Press, Ames 15: 494. Link: https://bit.ly/3vFUJRX

29. Yitayeh ZS, Bisetegn KB, Mindaye TT (2019) AMMI and GGE Analysis of GxE and Yield Stability of Early Maturing Sorghum [Sorghum bicolor (L.) Moench] Genotypes in Dry Lowland Areas of Ethiopia. Adv Crop Sci Tech 5: 425. Link: https://bit.ly/3w59e1V

30. Semahegn Z, Teressa T, Temesgen Begna ZA, Yali W, Gichele $H$, et al (2020) Evaluation of High Land Sorghum (Sorghum bicolor L. Meonch) Varieties for Yield Performance. Journal of Natural Science Research. Link: https://bit.ly/3H59LXu
Discover a bigger Impact and Visibility of your article publication with Peertechz Publications

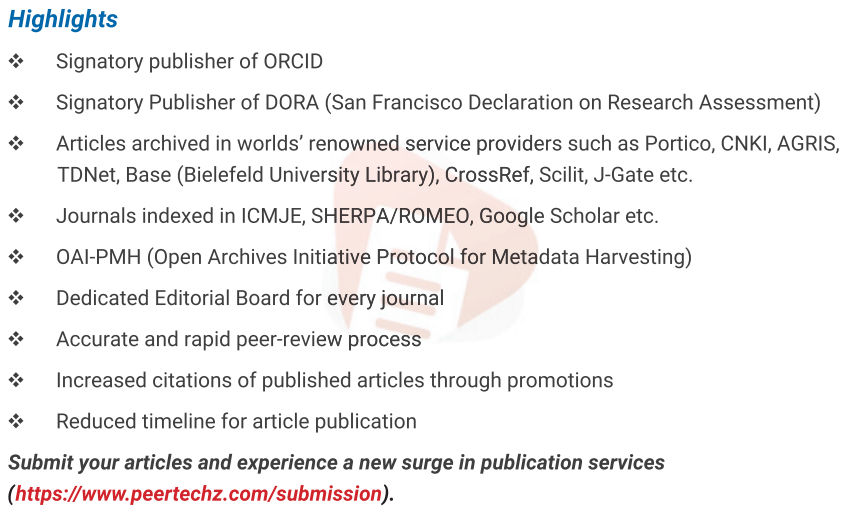

Citation: Semahegn Z, Teressa T (2021) Review of highland sorghum improvement research in Ethiopia. J Agric Sc Food Technol 7(3): 335-340. 